\title{
IDENTIFIKASI JENIS-JENIS KAYU PADA RUMAH ADAT EMA OWAA SUKU MEE DI KAMPUNG DAMABAGATAN KECAMATAN TIGI TIMUR KABUPATEN DEIYAI PROVINSI PAPUA
}

\author{
Lanny Wattimena ${ }^{1}$ \\ Universitas Victory Sorong \\ lannywattimena@gmail.com \\ Yetti S. Serkadifat ${ }^{2}$ \\ siskayetty7@gmail.com \\ Selpianus $\mathrm{Doo}^{3}$ \\ selpianusdoo@gmail.com
}

\begin{abstract}
ABSTRAK
Penelitian dengan judul "Identifikasi Jenis-jenis Kayu Pada Rumah Adat Ema Owaa Suku Mee di Kampung Damabagatan Kecamatan Tigi Timur Kabupaten Deiyai Provinsi Papua”, dilaksanakan selama 1 (satu) bulan yaitu pada bulan Juli sampai dengan Agustus 2019, berlokasi di Kampung Damabagata Distrik Tigi Timur Kabupaten Deiyai. Tujuan dari penelitian ini adalah untuk mengetahui jenis-jenis kayu apa saja yang digunakan dalam pembuatan rumah adat Ema Owaa oleh masyarakat Suku Mee. Hasil Penelitian menunjukkan bahwa jenis-jenis kayu dan non kayu yang dimanfaatkan sebagai bahan baku komponen rumah adat sebanyak 20 jenis yang terdiri dari 18 jenis kayu, yaitu: Samurai (Papuana kobuski), Petanan (Oblongifolia dyer), Magis Fagrae (Canarium decumanium), Kopal (Papuana dryer), Tawan (Laphopetalium forsteniana mia), Kenawan (Dillenia papuana martenlli), Campiana Castanopsis (argentea A. DC), Bintania (Litsea ampare marr), Emeron (Kalohyllum congestiforium a.c.sm.), Homelama (Hopea similis sloot), Melinan (Syzygium papuasica, MP), Tatania (Adimandra forbesii baker ff), Ladus (Hopea papuana dels), Manalia (Scihizomelia serrata hochr), Gradium (Homalium tomentosum, Roxb.), Tagal (Syzgium buettrianium), Sendania (Calophetalium fsteniana mia), Giatana (Homolantus tonsum, Roxb). Serta 2 jenis non kayu yaitu: Pandanus $(P$. Amaryllifolius, sp), Alonialan (Bambusa, sp).
\end{abstract}

Kata kunci : Jenis-jenis Kayu, Rumah Adat, Suku Mee.

\section{Abstract}

The research entitled "Identification of Wood Types in the Ema Owaa Traditional House of the Mee Tribe in Damabagatan Village, Tigi Timur District, Deiyai Regency, Papua Province", was carried out for 1 (one) month from July to August 2019, located in Damabagata Village, Tigi District East of Deiyai District. The purpose of this study was to find out what types of wood were used in the manufacture of the Ema Owaa traditional house by the Mee Tribe. The results showed that the types of wood and non-timber used as raw materials for traditional house components were 20 species consisting of 18 types of wood, namely: Samurai (Papuana kobuski), Petanan (Oblongifolia dyer), Magis Fagrae (Canarium decumanium), Kopal (Papuana dryer), Tawan (Laphopetalium forsteniana mia), Kenawan (Dillenia papuana martenlli), Campiana Castanopsis (argentea A. DC), Bintania (Litsea ampare marr), Emeron (Kalohyllum congestiforium a.c.sm.), 
Homelama (Hopea similis sloot), Melinan (Syzygium papuasica, MP), Tatania (Adimandra forbesii baker f), Ladus (Hopea papuana dels), Manalia (Scihizomelia serrata hochr), Gradium (Homalium tomentosum, Roxb.), Tagal (Syzgium buettrianium), Sendania (Calophetalium fsteniana mia), Giatana (Homolantus tonsum, Roxb.). And 2 types of non-timber namely: Pandanus (P. Amaryllifolius, sp), Alonialan (Bambusa, sp).

Keywords: Types of Wood, Traditional Houses, Mee Tribe.

\section{PENDAHULUAN}

Sumber daya hutan merupakan salah satu sumber daya alam yang begitu potensial dan merupakan tumpuan bagi keberlangsungan hidup suatu insan biologis. Hutan merupakan rumah dan sekaligus bank yang mensupalai kebutuhan hidup mendasar dari aktor biologis. Hal ini sangat mencolok dalam pola kehidupan masyarakat sekitar hutan. Dimana hutan memberikan kontribusi besar baik untuk memenuhi kebutuhan hidup seharihari dalam rumah tangga atau sebagai sumber penghasilan. Salah satu hasil kekayaan hutan adalah kayu. Kayu banyak dimanfaatkan untuk membuat meubel dan rumah. Selain rumah sebagai tempat tinggal, ada juga sebagai rumah adat. Rumah adat banyak ditemukan di seluruh daerah yang ada di Indonesia. Bahan yang dibutuhkan dalam pembuatan rumah adat adalah kayu dengan jenis kayu yang berbeda-beda (Mandang, 2012).

Indonesia memiliki kebudayaan yang beragam. Salah satunya ialah bangunan tradisional dari setiap suku yang dikenal dengan rumah adat. Rumah adat merupakan bangunan yang memiliki ciri khas khusus yang digunakan sebagai tempat tinggal oleh suatu suku bangsa tertentu (Turnip, 2010). Sampai saat ini masih banyak suku atau daerah di Indonesia yang tetap mempertahankan keberadaan rumah adat sebagai usaha untuk memelihara nilai-nilai budaya. Rumah adat tertentu biasanya dijadikan sebagai tempat tinggal, tempat pertemuan (aula) dan tempat tidur.

Rumah adat memiliki bentuk dan arsitektur masing-masing daerah sesuai dengan budaya adat lokal. Provinsi Papua memiliki 150-an jenis rumah adat. Rumah adat di Papua pada umumnya memiliki bentuk persegi tiga dengan arsitektur tradisional yang sudah jarang ditemukan. Sebagian sudah punah dan yang masih tersisa rata-rata bangunan yang sudah tua serta tidak terawat. Rumah adat yang sudah mengalami rusak parah kemudian dibangun kembali dengan bentuk bangunan yang lebih moderen atau dibiarkan begitu saja. Pembangunan kembali rumah adat seperti bentuk awal maupun menyerupai bangunan sangat jarang ditemukan. Hal ini nantinya dapat menyebabkan punahnya keberadaan rumah adat yang merupakan salah satu bentuk peninggalan budaya. Menurut Purba (2015), tindakan renovasi sangat dibutuhkan agar keberadaan rumah adat tetap terjaga dan lestari. Tindakan tersebut jika tidak dilaksanakan maka dapat memberikan dampak negatif bagi perkembangan budaya yang mengakibatkan banyaknya generasi muda yang nantinya tidak dapat melihat bangunan tradisional dari daerahnya sendiri (Radam, 2015).

Kabupaten Deiyai, merupakan daerah yang masih mempertahankan keberadaan rumah adat. Salah satunya adalah Rumah Adat Suku Mee yang beberapa bagian pada 
sisinya memiliki bentuk, motif, dan karakteristik yang khas. Bangunan Rumah Adat Suku Mee didominasi oleh bahan kayu. Ketersediaan jenis kayu yang menjadi unsur utama dalam pembangunan rumah adat sudah sulit diperoleh sehingga tidak mendukung berlangsungnya pembangunan dan dapat mengancam keberadaan serta kelestarian rumah adat tersebut. Secara tidak langsung kayu memiliki peran penting sebagai penyangga rumah adat. Jenis kayu yang cocok digunakan pada bangunan Rumah Adat Suku Mee harus diketahui terlebih dahulu sehingga dapat dilakukan upaya pelestarian. Hal tersebut dapat mendukung dilakukannya pembangunan kembali rumah adat yang sudah mengalami kerusakan.

Penelitian ini bertujuan untuk mengetahui jenis-jenis kayu yang digunakan sebagai bahan baku pembuatan rumah adat Suku Mee di Kampung Damabagata Distrik Tigi Timur Kabupaten Deiyai.

\section{KAJIAN TEORI}

Pengertian Identifikasi

Kegiatan penentuan jenis kayu (identifikasi jenis kayu) merupakan salah satu bagian dari rangkaian kegiatan pengujian dalam arti luas yaitu menentukan jenis kayu, mengukur dimensi kayu untuk mendapatkan volume serta menetapkan mutu. Penentuan jenis kayu pada hakekatnya bukan hanya sekedar untuk memenuhi persyaratan dalam pelaksanaan pengujian. Identifikasi adalah tugas untuk mencari dan mengenal ciri-ciri taksonomik individu yang beraneka ragam dan memasukan kedalam suatu takson. Identifikasi berkaitan erat dengan ciri - ciri taksonomik dan akan menetun sebauh sampel kedalam suatu urutan kunci identifikasi. Ditinjau dari segi ilmiah, identifikasi sangat penting artinya karna seluruh urutan pekerjaan selanjutnya tergantung hasil identifikasi yang benar dari suatu sampel yang sedang diteliti (Mayr Ashloek, 1991).

Karateristik Jenis-jenis Kayu

1. Pengertian Kayu

Kayu merupakan hasil hutan dari sumber kekayaan alam, dan merupakan bahan mentah yang mudah diproses untuk dijadikan barang sesuai kemajuan teknologi. Menurut Dumanauw (1990), kayu adalah suatu bahan yang diperoleh dari hasil pemungutan pohonpohon di hutan, yang merupakan bagian dari pohon tersebut dan bagian-bagian lain yang lebih banyak dapat dimanfaatkan untuk suatu tujuan penggunaan, baik berbentuk kayu pertukangan, kayu industri maupun ayu bakar.

Menurut Haygreen (1993) kayu merupakan material yang termasuk salah satu bahan bangunan yang berasal dari tumbuhan. Kayu adalah suatu karbohidrat yang tersusun terutama atas karbon, hidrogen, dan oksigen. Kayu mengandung senyawa anorganik yang tetap tinggal setelah terjadi pembakaran pada suhu tinggi dengan oksigen yang melimpah, residu semacam ini dikenal sebagai abu.

2. Jenis Kayu

Dumanauw (1982) mengatakan bahwa kayu merupakan bahan mentah yang didapatkan dari kekayaan alam. Sebelum memasuki proses pengolahan sebaiknya pengolah atau produsen sudah mengetahui sifat dan kategori kayu. Kayu dikategorikan atau diklasifikasikan ke dalam dua jenis yaitu, kayu keras (hard wood) dan kayu lunak 
(soft wood). Keduanya termasuk dalam divisi spermatophyta yang berarti tumbuhan berbiji. Kayu lunak memiliki daun yang menyerupai jarum, sedangkan kayu keras memiliki daun yang lebih lebar.

3. Fungsi Kayu

Dalam sebuah bangunan pasti ada bagian yang dinamakan struktur, dimana sistem tersebut menjadi suatu penahan beban yang ada pada bangunan. Sebagai bahan struktur kayu mempunyai berbagai kekuatan berdasarkan gaya yang bekerja (Dumanauw, 1982), yaitu sebagai berikut :

a. Menahan tarikan

b. Menahan tekanan (desak)

c. Menahan lentur

d. Menahan geser

4. Diameter

Penaksiran volume pohon dari sampel lapangan dan tegakan dilakukan melalui pengukuran karateristik dari pohon tersebut seperti diameter, tinggi dan tebal kulit. Dalam volume tegakan sangat penting dan diperlukan dalam pemanenan. Volume pohon merupakan fungsi dari tinggi dan diameter pohon (Simon, 2007). Bentuk batang berkaitan dengan perubahan diameter batang karen perubahan tinggi pengukuran. Penampang melintang suatu batang pada umumnya tidak teraturseperti pada bentuk lingkaran. Dibagian pangkal pohon, bentuk penampang lintang tersebut bahkan sangat jauh berbeda dengan bentuk lingkaran. Ketidakteraturan bentuk batang dipangkal pohon ini disebabkan karena pengaruh arah angin yang tetap dan lereng. Adapula penelitian berpendapat bahwa bentuk batang menyerupai elips tersebut ada kaitannya dengan bidang maknetik bumi. Banayk pohon-pohon tropis yang memiliki akar banir atau akar papan, yang membuat penampang lintang pohon sama sekali tidak menyerupai lingkaran atau elips (Herwiyono, 2000).

Bentuk penampang lintang bagian pangkal pohon yang cenderung eksentik itu maka dalam pengukuran diameter diambil pada setinggi dada, tidak lebih rendah dari itu. Bahkan untuk pohon-pohon berbanir, yang tingginya sering mencapai 2 meter atau lebih, pengukuran diameter harus dilakukan pada 20-25 cm diatas ujung banir. Untuk pohonpohon yang tidak berbanir ternyata ada korelasi yang kuat antar diameter setinggi dada dengan volume batang ternyata ada kelemahan (Dephut, 1998).

5. Warna Kulit Kayu

Ada beraneka macam warna, antara lain warna kuning, keputih-putihan, coklat muda, coklat tua, kehitam-hitaman, kemerah-merahan dan lain sebagainya. Hal ini disebabkan oleh zat-zat pengisi warna dalam kayu yang berbeda-beda. Warna suatu jenis kayu dapat dipengaruhi oleh faktor-faktor berikut: tempat didalam batang ,umur pohon, kelembapan udara. Pada umumnya warna suatu jenis kayu bukanlah warna yang murni, tetapi campuran beberapa jenis warna.

6. Daun

Daun merupakan suatu bagian tumbuhan yang penting dan pada umumnya tiap tumbuhan mempunyai sejumlah besar daun. Alat ini hanya terdapat pada batang saja dan tidak pernah terdapat pada bagian lain pada tubuh tumbuhan. Bagian batang tempat duduknya atau melekatnya daun dinamakan buku-buku (nodus) batang dan tempat diatas 
daun yang merupakan sudut antara batang dan daun dinamakan ketiak daun (axilla). Daun biasanya tipis melebar, kaya akan suatu zat berwarna hijau yang dinamakan klorofil, oleh karena itu daun biasanya berwarna hijau dan menyebabkan tumbuhan atau daerah-daerah yang ditempati tumbuh-tumbuhan nampak hijau pula (Tjitrosoepomo, 2001).

\section{METODOLOGI PENELITIAN}

\section{Waktu dan Tempat Penelitian}

Penelitian ini dilaksanakan pada bulan Juli sampai dengan Agustus 2019, di Kampung Damabagata Kecamatan Tigi Timur Kabupaten Deiyai.

\section{Alat dan Objek Penelitian}

Alat yang digunakan dalam penelitian ini adalah alat tulis menulis, kamera, meter, serta buku identifikasi jenis-jenis kayu. Objek penelitian adalah jenis-jenis kayu yang digunakan dalam pembuatan rumah adat Suku Mee di Kampung Damabagata Distrik Tigi Timur Kabupaten Deiyai.

\section{Sumber Data}

\section{Data Primer}

Data Primer adalah data yang dikumpulkan secara langsung di lapangan selama penelitian berlangsung, yaitu berupa jenis-jenis kayu yang digunakan dalam pembuatan rumah adat Suku Mee di Kampung Damabagata Distrik Tigi Timur Kabupaten Deiyai.

\section{Data Sekunder}

Data Sekunder adalah data yang dikumpulkan dari berbagai sumber baik itu buku, jurnal, laporan, serta data pendukung dari dinas terkait yang relevan tentang identifikasi jenis-jenis kayu yang digunakan dalam pembuatan rumah adat Suku Mee di Kampung Damabagata Distrik Tigi Timur Kabupaten Deiyai.

\section{Metode Pengumpulan Data}

Metode pengumpulan data pada penelitian ini dilakukan dengan cara observasi, wawancara, dokumentasi dan studi literature (buku panduan). Wawancara dilakukan pada 11 (sebelas) responden dengan tingkat umur antara 34-64 tahun yang memiliki mata pencaharian sebagai petani. Data yang dikumpulkan dalam penelitian ini meliputi: jenisjenis kayu yang digunakan dalam pembuatan rumah adat Suku Mee di Kampung Damabagata Distrik Tigi Timur Kabupaten Deiyai.

\section{Metode Analisis Data}

Metode analisis data yang digunakan adalah Analisis Data Kualitatif, yaitu proses secara sistematis mencari dan mengolah berbagai data yang bersumber dari wawancara, pengamatan lapangan, dan kajian dokumen (pustaka) untuk menghasilkan suatu laporan temuan penelitian. 


\section{HASIL DAN PEMBAHASAN}

\section{Jenis-Jenis dan Karasteristik Kayu}

Masyarakat di daerah pedesaan cenderung membangun rumah dengan menggunakan bahan-bahan lokal, bentuk sederhana dan ukuran yang bervariasi dsesuaikan dengan adat dan sifat tradisionalnya. Pemilihan jenis kayu sebagai bahan baku komponen bangunan rumah adat Ema Owaa dulunya memanfaatkan jenis-jenis kayu keras dan berdiameter besar yang ada di hutan sekitar Kampung Damabagata. Namun, tidak semua jenis kayu dapat digunakan sebagai bahan baku komponen rumah adat Ema Owaa. Menurut Nova (2012), yang menyatakan bahwa rumah kayu cenderung memiliki bahan bangunan yang ringan, namun bila tidak memperhatikan maka pada prinsipnya bisa terjadi kesalahan dalam rumah terutama dalam hal pemilihan bahan bangunan. Sebagai contoh, jika menggunakan jenis kayu yang berat pada kuda-kuda atap maka saat terjadi gempa struktur bagian bawah akan mengalami kerusakan karena struktur atas yang terlalu berat.

Data penelitian diambil berdasarkan wawancara dengan 11 (sebelas) responden dengan tingkat umur 34-64 tahun. Responden adalah orang yang dimintai jawaban terhadap pertanyaan yang diajukan, yang pekerjaannya adalah sebagai petani.

Jenis-jenis tumbuhan kayu yang dimanfaatkan oleh masyarakat Damabagata untuk pembuatan rumah adat, berdasarkan hasil penelitian ditemukan 18 jenis kayu yang digunakan dalam pembuatan rumah adat Ema Owa. Sedangkan jenis-jenis tumbuhan non kayu sebagai bahan pendukung dalam pembuatan rumah adat Ema Owaa adalah sebanyak

\section{2 jenis.}

Berdasarkan hasil wawancara yang dilakukan, maka jenis-jenis kayu yang biasa digunakan oleh Suku Mee untuk pembuatan rumah adat Ema Owaa adalah sebagai berikut: 1. Samurai (Papuana kobuski)

Jenis kayu Samurai adalah yang berwarna kulit kayu putih dan bergaris-garis di sepanjang batang maupun rantingnya. Diameter kayu mayoritas antara 50-100 cm dengan panjang tinggi antara 7-18 meter, dan bentuk daun bangun bulat telur tidak terlalu panjang dan tidak terlalu lebar dan bunga dengan buah tidak atau jarang berbuah. Sedangkan akar pada kayu tersebut itu akar berbanir, tempat bertumbuh pada tanah yang kering. Tunas kayu samurai yang masih mudah atau baru muncul dengan ketinggian sekitar $20 \mathrm{~cm}$ dari permukaan tanah, dapat dimanfaatkan sebagai kayu bakar, pagar dan sebagainya.

\section{Petanan (Oblongifolia dyer)}

Jenis kayu petanan adalah kayu yang kulit batangnya berwarna puth dan mengkilap. Diameter petanan ini berkisar antara 8-15 cm, dan bentuk daun bangun bulat telur tidak terlalu panjang dan tidak terlalu lebar dan biasa berbunga tetapi buah tidak atau berbuah. Sedangkan akar pada kayu tersebut itu akar berbanir. Sedangkan panjang atau tingginya sekitar 45-75 meter. Tumbuhnya di tempat yang kering maupun basah. Tumbuhnya mencapai 3-4 tahun langsung dapat dipanen untuk pembuatan rumah adat Ema Owaa oleh masyarakat setempat. 


\section{Magis Fagrae (Canarium decumanium)}

Jenis kayu mangis adalah salah satu jenis kayu yang memiliki ukuran lingkar batang yang cukup besar dan diameter $34-75 \mathrm{~cm}$. Jenis Magis memiliki nama lokal yang berada di setiap wilayah di Indonesia seperti sebutan maiy dari suku mee di Kabupaten Deiyai. Bentuk daun tidak terlalu panjang dan tidak terlalu lebar dan bunga, serta buah tidak atau jarang berbuah. Sedangkan akar pada kayu tersebut adalah akar pelekat, tempat bertumbuh pada tanah yang kering

Jenis kayu magis yang masih ditutupi oleh lapisan berwarna hitam dan bertekstur seperti kain berludru. Tinggi pohon magis dapat mencapai 10 kaki sedangkan lingkar batangnya dapat mencapai $8 \mathrm{~cm}$, memliki batang berkayu dan berdinding tebal yaitu antara 10 sampai $20 \mathrm{~mm}$. Bagian bawah terdapat node akar udara. Batang magis terdiri dari ruasruas, panjang setiap ruas antara 20 hingga $45 \mathrm{~cm}$ serta berwarna hitam kemerahan. Daun tumbuhan ini berbentuk tombak dengan panjang sekitar $15 \mathrm{~cm}$ hingga $30 \mathrm{~cm}$ dan lebarnya antara $10 \mathrm{~mm}$ hingga $25 \mathrm{~mm}$.

\section{Kopal (Papuana dryer)}

Jenis kayu kopal adalah kayu yang sangat mirip warnanya dengan kayu magis, perbedaanya terletak pada diameternya yang jauh lebih kecil dan tingginya yang pada umumnya maksimal 5 meter. Jarak antara ruas yang satu dengan yang lain cukup panjang dan di mafaatkan sebagai tiang rumah, vondasi rumah dan pagar. Sedangkan bentuk daun bangun jarum tidak panjang dan daun tipis dan bunga dengan buah tidak atau jarang berbuah. Sedangkan akar pada kayu tersebut itu akar lutut, tempat bertumbuh pada tanah yang basah atau tanah padang gurun.

\section{Tawan (Laphopetalium forsteniana mia)}

Tawan adalah jenis kayu yang tumbuh pada tempat basah kemudian kayu tidak terlalu tumbuh besar terkisar sampai 5-15 cm, ketinggian tawan tersebut 4-10 meter. Tawan ini dimanfaatkan untuk kayu buat untuk mmbuat rumah adat, pagar, jenis tawan ini tumbuh merumpun tingginya bisa mencapai $20 \mathrm{~m}$ dengan warna merah kekuningan, batangnya tidak bercabang di bagian bawah diameternya $2,5-15 \mathrm{~cm}$, tebal dinding 6-13 $\mathrm{mm}$ dan panjang satu ruas $45-65 \mathrm{~cm}$ panjang batang yang dapat dimanfaatkan antara 3-15 $\mathrm{m}$, mulai dari dataran rendah sampai ketinggian $1.000 \mathrm{~m}$ dpl. Bentuk daun bangun bulat telur tidak terlalu panjang dan tidak terlalu lebar dan bunga dengan buah tidak atau jarang berbuah. Sedangkan akar pada kayu tersebut itu akar berbanir, tempat bertumbuh pada tanah yang kering atau basah.

\section{Kenawan (Dillenia papuana martenlli)}

Kayu kenawan adalah jenis kayu yang kulitnya kayu berwarna hitam bergaris-garis disepanjang batang maupun rantingnya. Diameter kayu mayoritas antara 5-12 cm dengan panjang tinggi antara 7-18 meter. Kenawan ini nama bahasa daerah adalah Aga dan dengan ketinggian sekitar maksimal $20 \mathrm{~cm}$ dari permukaan tanah. Sedangkan bentuk daun adalah bangun bulat telur, panjang dan tidak terlalu lebar dan berbunga tapi buah tidak/jarang berbuah. Sedangkan akar pada kayu tersebut adalah akar berbanir, tempat 
bertumbuh pada tanah yang basah, dapat dimanfaatkan sebagi kayu bakar, pagar, kudakuda dan sebagainya.

\section{Campiana Castanopsis (argentea A. DC)}

Campiana adalah jenis kayu yang kulit batangnya berwarna hijau dan kecoklatan. Diameter campiana ini berkisar antara 50-150 $\mathrm{cm}$. Sedangkan panjang atau tingginya sekitar 50-85 meter. Bentuk daun bangun bulat telur tidak terlalu panjang dan tidak terlalu lebar dan bunga dengan buah tidak atau jarang berbuah. Sedangkan akar pada kayu tersebut itu akar berbanir, tempat bertumbuh pada tanah yang kering Tumbuhnya di tempat yang kering maupun basah. Tumbuhnya mencapai 7-8 tahun. Dan dapat dimanfaatkan sebagai papan rumah, tiang rumah, pagar dan kayu bakar.

\section{Bintania (Litsea ampare marr)}

Bintania adalah salah satu jenis kayu yang memiliki ukuran batang yang cukup besar dan termasuk ke dalam kayu lebih besar hampir sama dengan kayu campiana dan ladus. Tumbuhan kayu Bintania yang masih ditutupi oleh lapisan berwarna coklat dan bertekstur seperti bula. Tinggi kayu Bintania dapat mencapai 10 kaki sedangkan lingkar batangnya dapat mencapai $150 \mathrm{~cm}$. kayu Bintania memiliki batang berkayu dan berdinding tebal yaitu antara 10 sampai $20 \mathrm{~mm}$, dan bentuk daun bangun bulat telur tidak terlalu panjang dan tidak terlalu lebar dan bunga tidak keliatan tapi untuk berbuah banyak buat tidak terlalu besar. Sedangkan akar pada kayu tersebut itu akar berbanir, tempat bertumbuh pada tanah yang kering/basah. kemudian bagian yang dimanfaatkan adalah batang lalu untuk membuat papan cincang,tian cincang,pagar dan kayu bakar.

\section{Emeron (Kalohyllum congestiforium a.c.sm.)}

Kayu Emeron adalah kayu yang sangat mirip warnanya dengan kopal. Perbedaannya terletak pada diameternya yang jauh lebih kecil dan tinggi pada umumnya maksimal 5 meter. Jarak antara ruas yang satu dengan yang lain cukup panjang, dan bentuk daun bangun bulat telur tidak terlalu panjang dan tidak terlalu lebar dan bunga dengan buah tidak atau jarang berbuah. Sedangkan akar pada kayu tersebut itu akar berbanir, tempat bertumbuh pada tanah yang kering atau basah. Kemudian dimanfaatkan sebagai alang-alang atap dan kayu bakar.

\section{Homelama (Hopea similis sloot)}

Kayu homelama adalah jenis kayu yang berwarna merah, dalam bahasa lokal Deiyai terlebih khususnya untuk masyarakat yang ada di Kampung Damabagata biasanya disebut Onage . Homelama, dan bentuk daun bangun bulat telur tidak terlalu panjang dan tidak terlalu lebar dan berbunga dengan buah berbuah tapi buah yang kecil dan kecil. Sedangkan akar pada kayu tersebut itu akar berbanir, tempat bertumbuh pada tanah yang kering atau basah. Kayu ini dimanfaatkan untuk vondasi alas lantai, ataupun tiang untuk penahan, jenis kayu ini tumbuh merumpun tingginya bisa mencapai $20 \mathrm{~m}$ dengan warna merah cerah atau batangnya bercabang tapi tidah terlalu besar di bagian bawah diameternya $2,5-15 \mathrm{~cm}$, lalu biasanya tumbuh di tempat yang kering tidak lalu basah. 


\section{Melinan (Syzygium papuasica, MP)}

Kayu Melinan adalah kayu yang kulit batangnya berwarna hitam kecoklatn. Diameter melinan ini berkisar antara $8-15 \mathrm{~cm}$. Sedangkan panjang atau tingginya sekitar 10-19 meter. Tumbuhnya di tempat yang kering maupun basah, dan bentuk daun bangun bulat telur tidak terlalu panjang dan tidak terlalu lebar dan berbunga tapi jarang berbuah. Sedangkan akar pada kayu tersebut itu akar berlutut, tempat bertumbuh pada tanah yang kering atau basah. Tumbuhnya mencapai 2-4 tahun dan di manfaatkan sebagai bahan bangunan rumah adat Ema Owaa. Kemudian bahasa lokal di daerah Deiyai adalah Koa Tersebut.

\section{Tatania (Adimandra forbesii baker $f$.)}

Kayu tatania adalah salah satu jenis kayu yang memiliki ukuran lingkar batang yang cukup besar dan berdiameter 5-7 cm, dan bentuk daun bangun bulat telur tidak terlalu panjang dan tidak terlalu lebar dan bunga dengan buah tidak atau jarang berbuah. Sedangkan akar pada kayu tersebut itu akar berbanir, tempat bertumbuh pada tanah yang kering. Kayu tatania yang memiliki nama lokal yang berada dideiyai lebih khususnya Deiyai ialah Kenago dan dimanfaatkan sebagi bahan bangunan seperti pagar vondasi rumah.

\section{Ladus (Hopea papuana dels.)}

Kayu ladus adalah kayu yang sangat mirip warnanya dengan kayu campiana, perbedaanya terletak pada diameternya yang jauh lebih kecil dan tingginya yang pada umumnya maksimal 5-10 meter. Dan bentuk daun bangunan bulat telur tidak terlalu panjang dan tidak terlalu lebar dan bunga dengan buah tidak atau jarang berbuah. Sedangkan akar pada kayu tersebut itu akar berbanir, tempat bertumbuh pada tanah yang kering Jarak antara ruas yang satu dengan yang lain cukup panjang, untuk dapat di manfaatkan untuk bahan bangunan seperti tiang cincang, papan cincang, dan pagar.

\section{Manalia (Scihizomelia serrata hochr)}

Kayu ladus adalah kayu yang sangat mirip warnanya dengan kayu Campiana. Manalia artinya kayu ini tumbuh dihutan yang sangat dan sulit di temukan karya bisanya di buat busur dan panah kayu tersebut, manalia ini di manfaatkan untuk vondasi rumah, pagar, ataupun untuk dia buat busur dan panah, jenis manalia ini tumbuh merumpun tingginya bisa mencapai $20 \mathrm{~m}$ dengan warna putih kemerahaan. Sedangkan bentuk daun bangun bulat telur tidak terlalu panjang dan tidak terlalu lebar dan bunga dengan buah tidak atau jarang berbuah. Sedangkan akar pada kayu tersebut itu akar berbanir, tempat bertumbuh pada tanah yang kering batangnya tidak bercabang di bagian bawah diameternya $2,5-15 \mathrm{~cm}$.

\section{Gradium (Homalium tomentosum Roxb.)}

Kayu Gradium adalah kayu yang kulit kayu berwarna hitam kemerahan, postur batang halus disepanjang batang maupun rantingnya dan tidak terlalu besar. Diameter kayu mayoritas antara 4-10 cm dengan panjang tinggi antara 7-12 meter. Kayu gradium 
ini biasanya tumbuh pada tempat yang tidak terlalu terkena cahaya matahari lebih, dan berada dibawah cahaya dengan ketinggian sekitar maksimal $15 \mathrm{~cm}$ dari permukaan tanah, dan bentuk daun bangun bulat telur tidak terlalu panjang dan tidak terlalu lebar, bunga dengan buah tidak atau jarang berbuah. Sedangkan akar pada kayu tersebut adalah akar berbanir, tempat bertumbuh pada tanah yang kering dapat dimanfaatkan sebagi kayu bakar, kuda - kuda rumah dan kuda - kuda pagar.

\section{Tagal (Syzgium Buettrianium)}

Tagal adalah salah satu jenis kayu yang memiliki ukuran batang yang cukup besar. Kayu tagal memiliki nama lokal yaitu Aiyaidi. Kayu tagal memiliki diameter 15-20 Cm, bentuk daun bangun bulat telur tidak terlalu panjang dan tidak terlalu lebar, bunga dan buah tidak atau jarang berbuah. Sedangkan akar pada kayu tersebut adalah akar berbanir. Tempat bertumbuh pada tanah yang kering, panjang atau ketinggian 10-40 meter. Kayu tagal yang dapat dimanfaatkan sebagai kayu buah atau tiang rumah, pagar dan kayu bakar.

\section{Sendania (Calophetalium fsteniana mia)}

Kayu sendania adalah kayu yang sangat mirip warnanya dengan Ladus. Perbedaannya terletak pada diameternya yang jauh lebih besar dan tingginya yang pada umumnya maksimal 15-30 meter. Kayu sendania yang dapat dimanfaatkan adalah adalah tiang, kayu buah ataupun kayu kabar. Bentuk daunnya bulat telur tidak terlalu panjang dan tidak terlalu lebar, sedangkan bunga dan buah jarang berbuah. Akar pada kayu tersebut adalah akar berbanir, tempat tumbuh pada tanah yang kering. Kulit kayu digunakan sebagai alang-alang atap rumah untuk menutup rumah tersebut.

\section{Giatana (Homolantus tonsum Roxb)}

Kayu giatana adalah kayu yang sangat mirip warnanya dengan melinan. Perbedaanya terletak pada diameternya yang lebih besar dan tingginya berkisar antara 1530 meter. Bentuk daun bangun bulat telur tidak terlalu panjang dan tidak terlalu lebar, sedangkan bunga dan buah jarang berbuah. Akar pada kayu tersebut adalah akar berbanir, tempat bertumbuh pada tanah yang kering. Bagian kayu giatana dapat dimanfaatkan untuk tiang, kayu buah untuk kayu kabar. Kayu giatana dalam bahasa daerah disebut Kopa.

Sedangkan jenis-jenis non kayu yang biasa digunakan oleh Suku Mee untuk pembuatan rumah adat Ema Owaa adalah sebagai berikut:

\section{Pandanus ( $P$. amaryllifolius, $s p$ )}

Jenis tumbuhan pandanus adalah jenis tumbuhan non kayu yang kulit kayunya berwarna kecoklatan bergaris-garis duri pada daun. Diameter kayu mayoritas antara 4-8 cm dengan panjang tinggi antara 4-7 meter. Pandanus yang tidak memiliki kayu atau non kayu, ketinggian sekitar maksimal $20 \mathrm{~cm}$ dari permukaan tanah, serta bentuk daun bangun jarum panjang dan tidak terlalu lebar, berbunga dan buah berbuah. Sedangkan akar pada kayu tersebut adalah akar berbanir, tempat bertumbuh pada tanah yang kering dapat dimanfaatkan sebagai daun untuk alang-alang atap, pagar dan sebagainya. 


\section{Alonialan (Bambusa, sp)}

Alonialan adalah tumbuhan yang kulit batangnya berwarna hijau dan mengkilap. Diameter kayu ini berkisar antara 3-5 cm. Sedangkan panjang atau tingginya sekitar 3-5 meter. Bentuk daun bangun jarum panjang dan tidak terlalu lebar dan berbunga buah. Sedangkan akar pada kayu tersebut adalah akar selabut, tempat bertumbuh pada tanah yang basah. Tumbuhnya mencapai 2-4 tahun, dan dapat langsung dipanen oleh masyarakat setempat untuk pembuatan rumah adat sebagai alang-alang rumah

Tabel 1. Bagian-bagian yang dimanfaatkan

\begin{tabular}{|c|c|c|c|}
\hline No & Jenis kayu & $\begin{array}{c}\text { Bagian yang } \\
\text { dimanfaatkan }\end{array}$ & Bentuk Pemanfaatan \\
\hline 1 & Samurai (Papuana kobuski) & Batang & $\begin{array}{l}\text { - Lantai rumah } \\
\text { - } \text { Pagar kebun } \\
\text { - Vondasi rumah }\end{array}$ \\
\hline 2 & Petanan (Oblongifolia dyer) & Batang & $\begin{array}{ll}\text { - } & \text { Kuda-kuda rumah } \\
\text { - } & \text { Vondasi rumah } \\
\text { - } & \text { Pagar rumah }\end{array}$ \\
\hline 3 & Magis Fagrae (Canarium decumanium) & Batang & $\begin{array}{l}\text { - Penahan rumah/cabang } \\
\text { - Tiang rumah } \\
\text { - Pagar kebun }\end{array}$ \\
\hline 4 & Kopal (Papuana dryer) & Batang & $\begin{array}{ll}\text { - } & \text { Tiang rumah } \\
\text { - } & \text { Vondasi rumah }\end{array}$ \\
\hline 5 & Tawan (Laphopetalium forsteniana mia) & Batang & - Kayu buah untuk kuda-kuda \\
\hline 6 & Kenawan (Dillenia papuana martenlli) & Batang & $\begin{array}{l}\text { - } \text { Tiang rumah } \\
\text { - Pagar rumah }\end{array}$ \\
\hline 7 & Campiana Castanopsis (argentea A. DC) & Batang & $\begin{array}{l}\text { - } \text { Tiang rumah } \\
\text { - Papan rumah }\end{array}$ \\
\hline 8 & Bintania (Litsea ampare marr) & Batang & $\begin{array}{l}\text { - } \text { Papan rumah } \\
\text { - Tiang rumah }\end{array}$ \\
\hline 9 & $\begin{array}{l}\text { Emeron (Kalohyllum congestiforium } \\
\text { a.c.sm.) }\end{array}$ & Batang & - Kayu buah untuk alang-alang \\
\hline 10 & Homelama (Hopea similis sloot) & Batang dan daun & $\begin{array}{l}\text { - } \text { Alang2 untuk lantai } \\
\text { - } \text { Alang2 atap } \\
\text { - } \quad \text { Daun untuk atap }\end{array}$ \\
\hline 11 & Melinan (Syzygium papuasica, MP) & Batang & - Pagar rumah \\
\hline 12 & Tatania (Adimandra forbesii baker $f$ ) & Batang & $\begin{array}{l}\text { - } \text { Tiang rumah } \\
\text { - Pagar kebun }\end{array}$ \\
\hline 13 & Ladus (Hopea papuana dels) & Batang & $\begin{array}{l}\text { - } \quad \text { Tiang rumah } \\
\text { - } \text { Pagar kebun } \\
\end{array}$ \\
\hline 14 & Manalia (Scihizomelia serrata hochr) & Batang & $\begin{array}{l}\text { - } \text { Panah } \\
\text { - } \text { Busur } \\
\text { Pagar }\end{array}$ \\
\hline 15 & Gradium (Homalium tomentosum, Roxb.) & Batang & - Alang-alang rumah \\
\hline 16 & Tagal (Syzgium buettrianium ) & Batang & $\begin{array}{l}\text { - } \text { Pagar kebun } \\
\text { - Kuda-kuda rumah }\end{array}$ \\
\hline 17 & Sendania (Calophetalium fsteniana mia) & Batang, kulit & $\begin{array}{l}\text { - Kuda-kuda untuk alas lantai } \\
\text { - Kulit untuk atap rumah }\end{array}$ \\
\hline 18 & Giatana (Homolantus Tonsum, Roxb) & Batang & $\begin{array}{l}\text { - } \text { Pagar kebun } \\
\text { - Kuda-kuda rumah }\end{array}$ \\
\hline 19 & Pandanus (P. amaryllifolius, $s p$ ) & $\begin{array}{c}\text { Daun dan } \\
\text { Batang }\end{array}$ & $\begin{array}{l}\text { - Alang2rumah } \\
\text { - Pagar kebun }\end{array}$ \\
\hline 20 & Alonialan (Bambusa, sp) & Daun & - Alang-alang atap \\
\hline
\end{tabular}

Sumber: Data diolah, 2019. 


\section{Bagian-bagian Kayu yang Dimanfaatkan untuk Pembuatan Rumah Adat}

Sejak dahulu masyarakat di Kampung Damabagata telah memanfaatkan kayu untuk memenuhi kebutuhan sehari-hari, salah satunya kayu dapat digunakan untuk pembuatan tempat tinggal.

Terdapat 3 (tiga) bagian dari tumbuhan jenis kayu yang dimanfaatkan yaitu batang, kulit dan daun/pucuk muda/daun tua. Bagian tumbuhan kayu yang paling banyak digunakan untuk pembuatan rumah adat Ema Owaa adalah bagian batang.

\section{KESIMPULAN}

1. Berdasarkan hasil penelitian ditemukan 18 jenis kayu dan 2 jenis non kayu yang dimanfaatkan oleh masyarakat Damabagata dalam pembuatan rumah adat Suku Mee. Jenis-jenis kayu yang dimanfaatkan yaitu: Samurai (Papuana kobuski), Petanan (Oblongifolia dyer), Magis Fagrae (Canarium decumanium), Kopal (Papuana dryer), Tawan (Laphopetalium forsteniana mia), Kenawan (Dillenia papuana martenlli), Campiana Castanopsis (argentea A. DC), Bintania (Litsea ampare marr), Emeron (Kalohyllum congestiforium a.c.sm.), Homelama (Hopea similis sloot), Melinan (Syzygium papuasica, MP), Tatania (Adimandra forbesii baker .f), Ladus (Hopea papuana dels), Manalia (Scihizomelia serrata hochr), Gradium (Homalium tomentosum, Roxb.), Tagal (Syzgium buettrianium), Sendania (Calophetalium fsteniana mia), Giatana (Homolantus tonsum, Roxb). Sedangkan jenis-jenis non kayu yaitu: Pandanus (P. Amaryllifolius, sp), Alonialan (Bambusa, sp).

2. Bagian-bagian dari tumbuhan jenis kayu yang dimanfaatkan oleh masyarakat di Kampung Damabagata, yaitu bagian batang, daun, dan kulit. Bagian tumbuhan kayu yang paling banyak digunakan untuk pembuatan rumah adat Ema Owaa adalah bagian batang.

\section{DAFTAR PUSTAKA}

Dumanauw, J.F. 1982. Mengenal Kayu. Jakarta: Penerbit Gramedia

Haygreen. J.G. dan Bowyer, J.L. 1993. Hasil Hutan dan Ilmu Kayu: Suatu Pengantar, diterjemahkan oleh Hadikusumo, S.A. dan Prawirohotmodjo, S. Gadjahmada. Yogyakarta: University Press

Herwiyono, E. 2000. Ilmu Ukur Kayu. Jakarta:IPB Perss

Mayr Ashaloek. 1991. Identifikasi Kayu dan Pengunaan Pada Rumah-Rumah Rakyat. Universitas Gunadarma. Depok.

Nova. 2012. Arsitektur Rumah Adat Honai. Depok: Universitas Gunadarma

Purba, 2015. Iditipiologi dan Keharifan Arsitektur Tradisional Suku Mee Papua. Yogyakarta: Universitas Kristen Duta Wacana

Radam. H. I. N. 2015. Atonomo Kayu Pengantar Sifat Kayu Sebagai Bahan Bangunan. Yayasan Penerbit Fakultas Kehutanan IPB Bogor.

Salim. M. S. 2008. Dasar Dasar Hukum Kehutanan. Jakarta: Sinar Grafika 
Simon, H. 2007. Metode Inventore Hutan. Yogyakarta: Pustaka Pelajar

Suyohadikusumo, J. 2013. Strategi Kebijakan Pengolahan Hutan Tropis. CV. Maju Bersama.

Tjitrosoepomo. 2001. Morfologi Tumbuhaan. Yogyakarta: Gadjahmada University Press

Yunus. E dan Y. Moye. 2007. Studi Studi Tipologi dan Kearifan Arsitektur 